\title{
ANÁLISIS DE LOS RECURSOS PRESUPUESTARIOS DEL DEPARTAMENTO EJECUTIVO MUNICIPAL DE SANTA FE PARA IMPLEMENTAR PROGRAMAS HABITACIONALES Y DE EMPLEO DIRIGIDOS A LA POBLACIÓN ASENTADA EN VILLAS DE EMERGENCIA (2011-2015)
}

\author{
Martín Carné (•) \\ Universidad Nacional del Litoral / CONICET
}

\section{RESUMEN}

En base a Cuentas de Inversión del Departamento Ejecutivo Municipal (DEM) de la ciudad de Santa Fe, el trabajo analiza la magnitud y la procedencia de los recursos presupuestarios destinados a implementar programas habitacionales y de empleo para la población asentada en villas de emergencia. Así, la investigación da cuenta de las capacidades estatales internas que refieren a disponibilidad de recursos financieros por parte del DEM. El documento recupera aportes de la perspectiva escalar para explorar cómo actores de las escalas nacional (Estado) o global inclusive (organismos internacionales de crédito, OIC) pueden condicionar las intervenciones del DEM. En este sentido, a pesar de que más de la mitad de sus recursos presupuestarios proceden de recaudaciones fiscales operadas conjuntamente por los estados nacional y provincial, la evidencia muestra que el DEM santafesino pudo instrumentar y solventar programas habitacionales y laborales de su propio diseño conceptual para atender la situación de los habitantes de villas de emergencia.

\section{PALABRAS CLAVE :}

capacidades estatales, programas habitacionales y de empleo, villas de emergencia.

(•) E-mail: carnetes@hotmail.com

\section{ABSTRACT}

Based on Investment Accounts of the Municipal Executive Department (MED) of Santa Fe, the paper analyzes the magnitude and sources of budgetary resources to implement housing and employment programs aimed to shantytown population. With this, the research seeks to account for the internal state capacities, particularly those related to the availability of financial resources. The document recovers theoretical contributions of spatial scale perspective to explore how actors from national (State) or global scale (international lending agencies) may condition political interventions of the MED. In this sense, even though more than half of their budgetary resources come from tax revenues operated by both federal and provincial states, the evidence show that the santafesinian MED could implement and fund housing and employment programs of their own conceptual design directed to attend the situation of the shantytown population.

\section{KEY WORDS :}

state capacities, housing and employment programs, shantytowns.

RECEPCIÓN: 10/12/16

ACEPTACIÓN FINAL: 24/08/17 